\title{
PEMANFAATAN TEKNOLOGI KOMUNIKASI SEBAGAI REFERENSI PEMBELAJARAN MAHASISWA STAIN TEUNGKU DIRUNDENG MEULABOH
}

\author{
Fransisca Tassia \\ STAIN Tengku Dirundeng Meulaboh \\ E-mail:fransiscatassia@staindirundeng.ac.id
}

\begin{abstract}
Abstrak
Dimasa pandemi dalam proses pembelajaran terkadang peserta didik pembelajaran Teknik Evaluasi semester 5 STAIN Teungku Dirundeng Meulaboh dihadapkan pada terbatasnya Sumber bacaan oleh mahasiswa. keberadaan media online sebagai salah satu sumber pembelajaran sangat membantu peserta didik. Penelitian ini mencoba menganalisis keberadaan sumber dari media online. Tujuan tulisan ini adalah untuk mengetahui sejauh mana penggunaan media online dapat membantu peserta didik Teknik Evaluasi dalam proses pembelajaran untuk mencari referensi pembelajaran. Temuan penelitian ini bahwa pembelajaran peserta didik pembelajaran Teknik Evaluasi semester 5 STAIN Teungku Dirundeng Meulaboh dengan menggunakan media online mendapat membantu peserta didik yang mengambil mata kuliah Teknik Evaluasi dalam menyelesaikan tugas pembelajaran mereka.
\end{abstract}

Kata kunci: Pembelajaran, referensi, media

\begin{abstract}
During the pandemic period, in the learning process, sometimes students in the 5th semester of STAIN Teungku Dirundeng Meulaboh learning were faced with limited reading sources by students. The existence of online media as a learning resource is very helpful for students. This study tries to analyze the existence of sources of online media. The purpose of this paper is to determine the extent to which the use of online media can help Evaluation Technique students in the learning process to find learning references. The finding of this research is that the learning of the 5th semester of the evaluation technique of STAIN Teungku Dirundeng Meulaboh learning by using online media can help students who take the Evaluation Technique course in completing their learning assignments.
\end{abstract}

Keywords: Learning Studies, Reference, Media

\section{PENDAHULUAN}

Belajar pada hakekatnya adalah suatu proses yang terjadi dalam diri manusia, dan menghasilkan perubahan yang ditampilkan dalam bentuk 
peningkatan kualitas dan kuantitas tingkah laku seperti peningkatan kecepatan, pengetahuan, sikap, kebiasaan, pemahaman, keterampilan. Dimasa pandemic covid 19 terjadi peralihan dalam proses belajar, dimana biasanya pembelajaran terjadi tatap muka didalam ruangan, dimasa pandemic pembelajaran tetap tatap muka tetapi berlangsung secara online. Mahasiswa yang mengambil mata kuliah tidak dibenarkan untuk datang ke kampus dan meminjam buku dengan bebas diperpustakaan karena pelayanan untuk perpustakaan terbatas. Hal ini juga berimbas kepada keterbatasan mahasiswa dalam mengakses buku untuk referensi pembelajaran diperpustakaan, karena pelayanan untuk meminjam buku pun terbatas.

Dengan kecanggihan teknologi komunikasi yang pesat sekarang ini, mahasiswa bisa memanfaatkan media online sebagai referensi materi pembelajaran, dengan menggunakana media online mahasiswa bisa dengan bebas mengakses informasi yang berhubungan dengan materi pembelajaran yang dibutuhkan. dalam pencarian materi tugas biasanya mahasiswa searching di google dengan menggetikkan materi yang akan dicari, tetapi sekarang pencarian bahan untuk materi pembelajaran lebih mudah banyaknya aplikasi peminjaman buku, seperti penggunaan aplikasi Pusnas, aplikasi ini bisa dengan mudah di download oleh mahasiswa dari smart phone. Banyak pilihan aplikasi yang bisa digunakan, tergantung mau memilih yang mana. Tentunya aplikasi ini sangat membantu mahasiswa dalam mencari buku referesi yang dibutuhkan, karena dalam aplikasi ini tersedi begitu banyak buku dengan bergagai macam kategori, seperti pendidikan, olahraga, seni, masih banyak lagi kategori lainnya yang memudahkan mahasiswa mencari buku yang diinginkan. Hal ini tentunya akan meningkatkan kembali semangat belajar mahasiswa dalam pembelajaran, karena diawal pandemic covid 19 mahasiswa sempat bingung dengan pembelajaran online dan bagaimana cara mengerjangan tugas yang telah diberikan nantinya.

Di era pandemi covid 19 ini, pemerintah melalui kemeterian Pendidikan dan kebudayaan, telah mengeluarkan surat edaran Nomor 4 Tahun 2020 tentang Pelaksanaan Kebijakan Pendidikan dalam Masa Darurat Penyebaran Corona Virus Disease (Covid-19). Dimana, salah satu poin penting dalam surat edaran 
tersebut adalah, kementerian pendidikan memutuskan bahwa bagi tenaga Guru dan Dosen untuk bekerja dari rumah (WFH), sementara murid dan mahasiswa belajar dari rumah.

Kemudian juga ada surat edaran dari Menpan RB No. 19 tahun 2020 tentang penyesuaian Sistem Kerja Aparatur Sipil Negara (ASN) dalam upaya pencegahan penyebaran Covid 19 di lingkungan instansi pemerintah. Sebagai ASN, guru dalam upaya melaksanakan proses pembelajaran perlu dilakukan secara online atau dalam jaringan (daring). Namun, pelaksanaan proses pembelajaran secara online memiliki beberapa kendala. Seperti kendala mencari sumber referensi dalam pembelajaran.

Dengan adanya keputusan untuk bekerja dan belajar dari rumah, maka penggunaan media online sebagai sarana belajar, sangat dibutuhkan. Kebutuhan ini tidak hanya sebatas belajar saja, tetapi juga dituntut untuk bisa digunakan sebagai mencari referensi pembelajaran.

Menurut Fajar Nuriansyah, pembelajaran daring akan menjadi sangat efektif jika memenuhi komponen esensial dalam pembelajaran yaitu diskursif, adaptif, interaktif dan reflektif dengan elemen-elemen yang akan sangat baik jika diintegrasikan dengan lingkungan pembelajar sehingga dapat menjadi pembelajaran daring yang terintegrasi dengan lingkungan atau memenuhi komponen digital learning ecosystem karena dapat mengakomodasi gaya belajar, fleksibilitas dan pengalaman belajar peserta didik sehingga dapat termemunculkan ${ }^{1}$.

Sebetulnya, penggunaan media online sebagai sarana untuk mencari sumber referensi, sudah lama digunakan, bahkan jauh sebelum pandemi covid 19. Namun, setelah adanya pandemi covid 19, penggunaan media online sebagai sumber referensi, makin dikenal luas dan makin dibutuhkan. Oleh karena itu, menurut Zuhdy Tafqihan, penggunaan media online harus dilakukan dengan tepat agar materi atau content tersampaikan dengan baik. Untuk memilih media online yang tepat sebagai sumber referensi ini, diperlukan infrastruktur yang tidak murah. Karena itu, diperlukan perencanaan agar

${ }^{1}$ Fazar Nuriansyah, 2020, Efektifitas Penggunaan Media Online Dalam Meningkatkan Hasil Belajar Pada Mahasiswa Pendidikan Ekonomi Saat Awal Pandemi Covid-19, Jurnal Pendididikan Ekonomi Indonesia, Vol. 1 No. 2, Mei 2020, hal.62 
infrastruktur seperti ini sebanding dengan tingkat penggunaan dan kebermanfaatannya ${ }^{2}$.

\section{LANDASAN TEORI}

\section{Belajar dan Pembelajaran}

Skinner berpandangan bahwa belajar adalah suatu perilaku. Pada saat orang belajar, maka responya menjadi lebih baik. Sebaliknya, bila ia tidak bejalar makan responnya menurun. Dalam belajar ditemukan adanya hal berikut: ${ }^{3}$

a. Kesempatan menjadi peristiwa yang menimbulkan respons pebelajar

b. Respon sipebelajar

c. Konsekwensi yang menguatkan respons tersebut, pemerkuat terjadi pada stimulus yang menguatkan konsekwensi tersebut. Sebagai ilustrasi, perilaku respons sipebelajar yang baik diberikan hadiah. Sebaliknya, perilaku respons yang tidak baik diberi teguran dan hukuman

Sedangkan menurut Gagne, belajar merupakan kegiatan yang kompleks. Hasil belajar merupakan kapabilitas. Setelah belajar orang memiliki keterampilan, pengetahuan, sikap, dan nilai. Timbulnya kapabilitas tersebut adalah dari: ${ }^{4}$

a. Stimulasi yang berasal dari lingkungan

b. Proses kognitif yang dilakukan oleh pebelajar. Dengan demikian belajar dalah seperangkat proses kognitif yang mengubah sifat stimulasi lingkungan, melewati pengolahan informasi, menjadi kapabilitas baru.

Pembelajaran adalah segala sesuatu yang dapat membawa informasi dan pengetahuan dalam interaksi yang berlangsung antara pendidik dengan peserta didik. Rogers mengemukakan saran tentang langkah-langkah pembelajaran yang perlu dilakukan oleh guru. Saran pembelajaran itu meliputi hal berikut ${ }^{5}$ :

2 Zuhdi Tafqihan, 2011, Karakteristik Dan Pemilihan Media Pembelajaran Dalam ELearning, Cendikia: Jurnal Kependidikan dan kemasyarakatan, Vol. 9 No. 2, 2011. Hal. 149

${ }^{3}$ Rifnon Zaini, 2014, Studi Atas Pemikiran B.F. Skinner Tentang Belajar, Terampil: Jurnal Pendidikan dan Pembelajaran Dasar, Vol. 1No. 1, Juni 2014, hal. 123 Winston

${ }^{4}$ Gagne, R. M.1970, The Conditins of Learning. (2nd ed). New York: Holt, Rinehart and

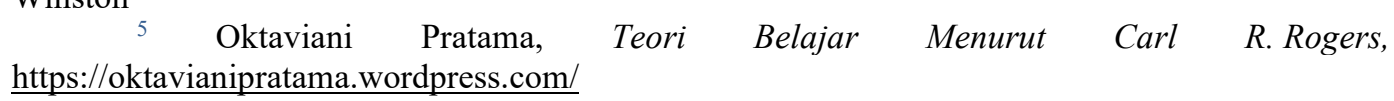


a. Guru memberikan kepercayaan kepada kelas agar kelas memilih belajar secara terstruktur.

b. Guru dan siswa membuat kontrak belajar

c. Guru menggunakan metode inkuiri, atau belajar menemukan (discovery learning).

d. Guru menggunakan metode stimulasi.

e. Guru menggunakan latihan sepekan agar siswa mampu menghayati perasaan dan berpartisipasi dengan kelompok lain.

f. Guru bertindak sebagai fasilitator belajar.

g. Sebaiknya guru menggunakan pengajaran terprogram, agar tercipta peluang bagi siswa untuk timbulnya kreativitas

Keempat pandangan tentang belajar tersebut merupakan bagian kecil dari pandangan yang ada. Untuk kepentingan pembelajaran, para guru dan calon guru masih harus mempelajari sendiri dari psikologi belajar. Disamping itu, para guru masih perlu memilih materi yang relevan bagi bidang studi yang diasuhnya. Guru juga perlu memodifkasi secara praktis sesuai dengan kondisi perilaku siswa belajar.

Dikarenakan belajar merupakan tindakan dan perilaku siswa yang kompleks. Sebagai tindakan, maka belajar hanya dialami oleh siswa sendiri. Siswa adalah penentu terjadinya atau tidak terjadinya proses belajar. Proses belajar terjadi berkat siswa memperoleh sesuatu yang ada dilingkungan sekitar. Lingkungan yang dipelajari oleh siswa berupa keadaan alam, benda-benda, hewan, tumbuh-tumbuhan, manusia, atau hal-hal yang dijadikan bahan belajar. Tindakan belajar tentang sesuatu tersebut tampak sebagai perilaku belajar yang tampak dari luar.

\section{Tujuan Belajar dan Pembelajaran}

Dalam segala kegiatan pasti mempunyai tujuan, begitu juga dengan belajar dan pembelajaran. Tujuan adalah pernyataan yang menyelaraskan hasil yang ingin dicapai atau tempat yang akan dituju. Maka tujuan belajar dan pembelajaran adalah pernyataan yang menjelaskan hasil yang ingin dicapai dalam perbuatan 
pembelajaran dengan kata lain, dapat diartikan sebagai suatu kondisi perubahan tingkah laku dari individu setelah individu tersebut melaksanakan proses belajar. Selanjutnya, Melalui belajar diharapkan dapat terjadi perubahan (peningkatan) bukan hanya pada aspek kognitif, tetapi juga pada aspek lainnya. Selain itu tujuan belajar yang lainnya adalah untuk memperoleh hasil belajar dan pengalaman hidup.

Sedangkan Tujuan pembelajaran adalah suatu pernyataan yang spesifik yang dinyatakan dalam perilaku atau penampilan yang diwujudkan dalam bentuk tulisan untuk menggambarkan hasil belajar yang diharapkan. Proses pembelajaran adalah proses membantu siswa belajar, yang ditandai dengan perubahan perilaku baik dalam aspek kognitif, afektif dan psikomotorik. Seorang guru hanya dapat dikatakan telah melakukan kegiatan pembelajaran jika terjadi perubahan perilaku pada diri peserta didik sebagai akibat dari kegiatan tersebut.

Hal ini memberi makna, bahwa di dalam proses pembelajaran guru tidak sekedar bertugas mentransfer pengetahuan, sikap dan keterampilan. Proses pembelajaran dipandang sebagai proses membantu peserta didik belajar, membantu peserta didik mengembangkan dan mengubah perilaku (kognitif, afektif dan psikomotorik); membantu menerjemahkan semua aspek tersebut ke dalam perilaku-perilaku yang berguna dan bermakna.

\section{Media online}

Istilah media online merupakan gabungan dua kata "media" dan "online". Dalam Kamus Kamus Besar Bahasa Indonesia (KBBI), Media adalah alat atau sarana komunikasi seperti koran, majalah, TV, Radio, dan lainnya. Sementara itu, kata "online" dalam bahasa Indonesia disebut dengan daring. Daring artinya “dalam Jaringan”, yaitu terhubung melalui internet. Berdasarkan hal tersebut, media online dapat diartikan sebagai media dalam jaringan yang terhubung melalui jaringan komputrer dan internet.

Dalam pengertian yang lebih umum lagi, media online dapat diartikan sebagai segala jenis atau format media yang hanya bisa diakses melalui internet berisikan teks, foto, video, dan suara. Dalam pengertian umum ini, media online juga bisa dimaknai sebagai sarana komunikasi secara online ${ }^{6}$.

\footnotetext{
${ }^{6}$ https://www.romelteamedia.com/2014/04/media-online-pengertian-dan.html
} 
Dalam artian khusus, media online hanya terkait dengan media dalam konteks komunikasi massa. Asep Syamsul M. Romli dalam buku Jurnalistik Online: Panduan Mengelola Media Online (Nuansa, Bandung, 2012) mengartikan media online sebagai berikut, "Media online adalah media massa yang tersaji secara online di situs web (website) internet”. Masih menurut Romli dalam buku tersebut, media online adalah media massa "generasi ketiga" setelah media cetak (printed media) koran, tabloid, majalah, buku- dan media elektronik (electronic media), radio, televisi, dan film/video. ${ }^{7}$

Dengan demikan, menurut Asep Syamsul M. Romli (2012), karakteristik media online yaitu: ${ }^{8}$

1. Multimedia Dapat memuat atau menyajikan berita/informasi dalam bentuk teks, audio, video, grafis dan gambar secara bersamaan.

2. Aktualitas Berisi info aktual karena kemudahan dan kecepatan penyajian.

3. Cepat Saat berita diposting atau diuploud, berita dapat langsung diakses oleh semua orang.

4. Update Pembaruan (updating) informasi dapat dilakukan dengan cepat baik dari sisi konten maupun redaksional, misalnya dalam kesalahan ketik/ejaan.

5. Kapasitas luas Halaman web bisa menampung naskah sangat panjang.

6. Fleksibilitas Pemuatan dan editing naskah bisa kapan saja dan dimana saja, juga jadwal terbit (update) bisa kapan saja, setiap saat.

Singkatnya, media online dapat dikatakan sebagai media komunikasi yang disajikan dalam secara online disitus internet.

\section{Pandemi Covid 19}

Pandemic Covid-19 adalah peristiwa menyerbarnya penyakit koronavirus 2019 diseluruh dunia untuk semua Negara. Penyakit ini disebabkan oleh koronavirus jenis baru yang diberi nama SARS-Co-2. Wabah Covid-19 pertama kali dideteksi dikota Wuhan, propinsi Hubei, Tiongkok pada tanggal 1 Desember 2019dan ditetapkan sebagai pandemic organisasi oleh organisasi kesehatan dunia

${ }^{7}$ Asep Syamsul M. Romli, 2012, Jurnalistik Online: Panduan Praktis Mengelola Media Online (Dilengkapi Kiat Blogger, Teknik Seo Dan Tip Media Sosial), (Bandung: Nuansa Cendekia) hal. 53

8 Ibid, Hal. 54 
(WHO) pada tanggal 11 Maret 2020. Hingga 14 November 2020, lebih dari 53.281.350 orang kasus telah diolaporkan lebih dari219 negara dan wilayah seluruh dunia, mengakibatkan lebih dari 1.301.021 orang meninggal dunia dan lebih dari 34.394.214 orang sembuh. ${ }^{9}$

Virus SARS-CoV-2 diduga menyebar diantara orang-orang terutama melalui percikan pernafasan (droplet) yang dihasilkan selama batuk. Percikan ini juga dapat dihasillkan dari bersin dan pernafasan normal. Selain itu Virus juga menyebar akibat menyentuh permukaan benda yang terkontaminasi dan kemudian menyentuh wajah seseorang. Penyakit Covid-19 paling menular saat orang menderitanya memiliki gejala, meskipun penyebaran terjadi sebelum penyebarab muncul. Periode waktu antara paparan virus dan muculny gejala biasanya sekitar lima hari, tetapi dapat berkisar antara dua hingga empat belas hari. Gejala umum diantaranya demam, batuk, sesak nafas, komplikasi dapat berupa peunomia dan penyakit pernafasan akut berat. Tidak ada vaksin atau pengobatan khusu untuk penyakit ini. Pengobatan promer yang diberikan berupa terapi simtomatik dan simportif. Langkah-langkah pencegahan yang direkomendasikan diantaranya mencuci tangan, menutup mulut saat batuk, menjaga jarak dari orang lain, serta pemantauan serta isolasi diri untuk orang yang mencurigai bahwa mereka terinfeksi. $^{10}$

Upaya untuk mencegah penyebaran virus corona termasuk pembatasan perjalanan, karantina dan pemberlakuan jam malam, penundaan dan pembatalan acara, serta penutupan fasilitas, upaya ini termasuk karantina Hubei, karantina nasional di Italia dan tempat lain di Eropa, serta pemberlakukan jam malam di Tiongkok dan Korea Selatan, sebagai penutupan perbatasan Negara atau pembatasan penumpang yang masuk, penapisan dibandara atau distasiun kereta, serta informasi perjalanan mengenai daerah yang transmisi lokal. Sekolah dan universitas ditutup baik secara nasional atau local di lebih dari 124 negara dan memengaruhi lebih dari 1,2 miliar siswa. Pandemic ini telah menyebabkan gangguan sosio ekonomi global, penundaan atau pembatalan acara oahraga dan $\frac{\text { covid-19/101490 }}{10 \quad \text { ht }}$

https://www.allianz.co.id/explore/detail/yuk-pahami-lebih-jelas-arti-pandemi-pada$\underline{\text { menular }}$ 
budaya, dan kekhawatiran luas tentang kekurangan persediaan barang yang mendorong pembelian panik. Misinformasi dan teori konspirasi tentang virus telah menyebar secara daring, dan telah terjadi insiden xenophobia dan rasisme terhadap orang tiongkok dan orang-orang asia timur atau asia tenggara lainnya.

\section{PEMBAHASAN}

\section{Media Online Sebagai Penyaji Informasi}

Seiring dengan perkembangan teknologi dan informasi, perkembangan media menjadi salah satu kemajuan yang tidak dapat dielakkan. Salah satu indikasinya adalah menjamurnya portal berita di internet saat ini tidak terlepas dari kebutuhan masyarakat untuk memperbarui informasinya bahkan dalam 19 hitungan detik dimanapun dan kapanpun. Keberadaan internet sebagai media baru dianggap sebagai gagasan yang revolusioner, dimana internet dapat menyebarkan informasi lebih luas dan tidak terikat oleh waktu, mereka dapat mengupload berita setiap jam, setiap menit bahkan detik dan lebih mudah untuk diakses. Bentuk pembaharuan yang dilakukan oleh internet salah satunya adalah konsep baru dan realitas dari portal Web.

Jika dilihat sisi positifnya, penggunaan media online sebagai sumber referensi dapat dikatakan bahwa media online memiliki kelebihan, seperti informasinya lebih bsersifat personal yang dapat diakses oleh siapa saja, kapan saja, dan di mana saja. Namun kelemahanya adalah, penggunaan media online sebagai sumber referensi juga harus didukung oleh perangkat komputer dan jaringan internet yang baik. Sebagaimana diketahui, bagi sebagian lapisan masayarakat, sampai saat ini biayanya relatif mahal. kemudian belum semua wilayah memiliki jaringan internet yang baik.

Pada sisi lain, segala fasilatas yang ditawarkan oleh internet menimbulkan kekhawatiran. Menurut Breen, sebagaimana penulis kutip dari DenisMcQuail, bahwa internet berkembang melampaui fase keterbukaan dan demokrasi kemudian menjadi layanan yang mampu membayar untuk menerima konten yang lebih bernilai. Dengan adanya internet sebagai media referensi, akan sangat 
memudahkan mahasiswa dalam mengakses dan mengupdate segala informasi yang dibutuhkan ${ }^{11}$.

Media online sebagai sumber referensi, bisa mempresentasikan diri ke ruang publik. Fenomena penggunaan media online dikalangan masyarakat, sudah berlangsung cukup lama. Informasi-informasi yang disajikan dalam media online sangat beragam, seperti politik, ekonomi, budaya, dan lain sebagainya. Penyajian informasi itu sekaligus menunjukan bahwa media online juga bisa memperkuat struktur dari informasi yang disampaikan. Bahkan, media online tidak hanya sebatas penyampai informasi ke masyarakat, bahkan lebih dari itu, yaitu bisa menjadi ideologi baru. Dengan begitu mudahnya mendapatkan informasi dengan beragam referensi yang tersedia di media online, jauh sangat memudahkan masyarakat, khususnya kalangan pelajar dan mahasiswa dalam proses pembelajaran, apalagi di era covid 19 ini, dimana semua proses belajar diharuskan dilakukan secara daring. Dari uraian di atas dapat dilihat, bahwa penggunaan media online sebagai penyaji informasi sangatlah dibutuhkan dalam proses pembelajaran. Penggunaan media online sebagai pemeberi informasi memiliki peran yang sangat penting.

\section{Media Online sebagai sumber referensi}

Dabbagh dan Ritland mengatakan ada tiga komponen pada pembelajaran online yaitu: (a) model pembelajaran, (b) strategi instruksional dan pembelajaran, (c) media pembelajaran online. Ketiga komponen ini membentuk suatu keterkaitan interaktif, yang didalamya terdapat model pembelajaran yang tersusun sebagai suatu proses sosial yang menginformasikan desain dari lingkungan pembelajaran online, yang mengarah ke spesifikasi strategi instruksional dan pembelajaran yang secara khusus memungkinkan untuk memudahkan belajar melalui penggunaan teknologi pembelajaran. ${ }^{12}$

Dalam pembelajaran Teknik Evaluasi Jurusan Tarbiyah STAIN Teungku Dirundeng Meulaboh semua peserta didik pembelajaran Teknik Evaluasi Teungku Dirundeng Meulaboh diberikan tugas berupa resume disetiap kali pertemuan,

11 Denis McQuail, 2012, Teori Komunikasi Massa, (Jakarta: Salemba Humanika), hal $152-153$

12 Dabbagh, N. and Ritland. B. B. (2005). Online Learning, Concepts, Strategies And Application. Ohio: Pearson, hal. 3-4 
dengan tujuan agar mereka mengetahui materi pembelajaran apa yang akan dibahas disetiap kali peretemuan, dinama resume yang dibuat oleh peserta didik berpedoman kepada rencana pembelajaran semester (RPS). Dalam mata kuliah Teknik Evaluasi Jurusan Tarbiyah STAIN Teungku Dirundeng Meulaboh Penggunaan media online sebagai sumber referensi pembelajaran yang berbasis multimedia merupakan salah satu solusi bagi pelajar dan peserta didik untuk mencari beragam informasi sebagai referensi pembelajaran. Seperti penelitian Ibrahim \& Suardiman menunjukkan bahwa ada pengaruh positif penggunaan elearning terhadap motivasi dan prestasi belajar peserta didik. Pada awalnya peserta didik pembelajaran Teknik Evaluasi merasa bingung untuk mengerjakan tugas, banyak dari peserta didik pembelajaran Teknik Evaluasi tidak mengumpulkan tugas terkendala sumber referensi, harus kemana untuk mancari sumber referensi dalam pembelajaran karena proses pembelajaran tidak dilakukan tatap muka didalam kelas melainkan dialihkan secara virtual seperti menggunakan zoom, classroom atau media online lainnya, mereka terfokus bahwa referensi pembelajaran akan lebih baik dengan meminjam buku langsung di perpustaakaan, dengan digunakannya media online sebagai sumber referensi dalam pembelajaran Teknik Evaluasi peserta didik menjadi jawaban atas kebingungan dalam mencari referensi pembelajaran, sehingga peserta didik bisa termotivasi kembali dalam proses pembelajaran, karena sebelumnya peserta didik pembelajaran Teknik Evaluasi Meulaboh merasa bingung dengan pembelajaran daring.

Peserta didik mengeluhkan kendala-kendala apa saja yang mereka hadapi selama pembelajaran dilakukan secara online, adapun keluhan yang dialami peserta didik sebagai berikut:

1. Jaringan internet yang kurang bagus, sehingga pada saat pembelajaran berlangsung penjelasan materi yang diberikan tidak bisa diterima dengan baik.

2. Keterbatasan peserta didik dalam mengakses buku diperpustakaan, karena tidak semua peserta didik memiliki buku sumber pembelajaran.

3. Kurang fahamnya peserta didik dalam menggunakan aplikasi online dalam proses pembelajaran. 
4. Keterbatasan peserta didik dalam membeli kuota internet yang dibutuhkan untuk proses pembelajaran.

Banyak pilihan aplikasi pustaka di media online yang bisa digunakan untuk mencari referensi dalam pembelajaran Teknik Evaluasi STAIN Teungku Dirundeng Meulaboh, salah satu aplikasi yang bisa digunakan seperti menggunakan aplikasi Pustaka Nasional (PusNas) dalam mencari buku yang sesuai dengan materi pembelajaran. Dalam prakteknya sangat mudah, peserta didik bisa langsung mendownload aplikasi Pusnas dismartphone, setelah aplikasi terpasang peserta didik bisa langsung menggunakan aplikasi tersebut untuk mencari buku yang di inginkan sebagai referensi pembelajaran. Hal ini tentunya sangat membantu peserta didik pembelajaran Teknik Evaluasi STAIN Teungku Dirundeng Meulaboh dalam mencari materi pembelajaran yang ditugaskan. Dalam proses pembelajaran secara virtual peserta didik pembelajaran Teknik Evaluasi STAIN Teungku Dirundeng Meulaboh dibebaskan untuk bertanya tentang materi yang diberikan. Hal ini bisa menjawab kekurang fahaman peserta didik terhadap materi pembelajaran yang telah mereka cari sebelumnya.

\section{KESIMPULAN}

Dengan adanya media online sangat membantu peserta didik pembelajaran Teknik Evaluasi Jurusan Tarbiyah STAIN Teungku Dirundeng Meulaboh dalam mencari referensi materi pembelajaran, sehingga peserta didik bisa mengatasi hambatan dalam mencari bahan materi pembelajaran khususnya pada pembelajaran Teknik Evaluasi.

Meskipun dalam masa pandemic covid 19 tidak menyurutkan semangat para peserta didik untuk terus melanjutkan pembelajaran, dengan menggunakan media online adalah salah satu cara yang dipakai sebagai referensi dalam pembelajaran.

Dengan menggunakan media online sebagai sumber referensi pembelajaran, secara tidak langsung dapat meningkatkan pemahaman peserta didk dalam menggunakan media online untuk proses pembelajaran. Tidak semua peserta didik sanggup untuk mengikuti pembelajaran secara online karena keterbatasan untuk memiliki akses internet. 


\section{DAFTAR PUSTAKA}

\section{Buku}

AEcT. Devinisi Teknologi Pendidikan. Jakarta: PAU-UT dan C.V. Rajawali. 1986.

Anastasi, anne. Bidang-Bidang Psikologi Terapan (Terjemahan Aryatmi Siswaharjo, dkk). Jakarta: Rajawali Press. 1989.

Arikunto, Suharsimi. Penilaian Program Pendidikan. Jakarta: Depdikbud. 1988.

Asep Syamsul M. Romli, Jurnalistik Online: Panduan Praktis Mengelola Media Online (Dilengkapi Kiat Blogger, Teknik Seo Dan Tip Media Sosial), Bandung: Nuansa Cendekia, 2012

Biggs, John B. \& tlfer, Roos. The Proses Of Learning. Sydney: Prentice-Hall Of Australia Pty Ltd. 1987.

Bloom, Benjamin S., et. Al. Evaluation to improve learning. New York: Inc., Graw-hill Book Company. 1961.

Dabbagh, N. and Ritland. B. B, Online Learning, Concepts, Strategies And Application. Ohio: Pearson, 2005.

Dimyati, Mujiono, Belajar Dan Pembelajaran. Jakarta: Depdikbuddan Rineka Cipta 2009.

Denis McQuail, Teori Komunikasi Massa McQuail, (Jakarta: Salemba Humanika, 2012.

Fazar Nuriansyah, 2020, Efektifitas Penggunaan Media Online Dalam Meningkatkan Hasil Belajar Pada Mahasiswa Pendidikan Ekonomi Saat Awal Pandemi Covid-19, Jurnal Pendididikan Ekonomi Indonesia, Vol. 1 No. 2, Mei 2020.

Hamdani MA. Strategi Belajar Mengajar. Bandung: C.V Pustaka Setia. 2011

Hisyam Zaini, Bernawy Munthe, sekar Ayu Aryani. Strategi Pembelajaran Aktif. Yogkarta: CTSD. 2004.

Hurlock. Psikologi Perkembangan (suatu pendekatan sepanjang rentang kehidupan). Jakarta: Erlangga. 1996.

Isjoni. Cooperatif Learning.Bandung: Alfabeta. 2007.

Kubicek, P. John. "Inquiri based learning, the nature of science, and computer technology: New possibilities in science education". Canadian Journal of Learning and Technology. Vol 31 (1). 2005.

Made Wena. Strategi Pembelajaran inovatif Kontemporer. Jakarta: Bumi Aksara. 2010.

Mayer, R. E, Multi Media Learning Prinsip-Prinsip Dan Aplikasi. Yogyakarta: Pustaka Pelajar, 2009.

Nurhadi. Kurikulum 2004. Pertanyaan dan Jawaban. Jakarta: Grasindo. 2004. 
Oemar Hamalik. Proses Belajar Mengajar. Jakarta: PT. Bumi Aksara. 2009.

Sadiman. Interaksi Dan Motivasi Belajar Mengajar. Jakarta: Remaja Grafindo. 2011

Ratna Wilis Dahar. Teorit-eori Belajar. Jakarta: Erlangga. 1989.

Rifnon Zaini, Studi Atas Pemikiran B.F. Skinner Tentang Belajar, Terampil: Jurnal Pendidikan dan Pembelajaran Dasar, Vol. 1No. 1, Juni 2014

Sumadi Suryabrata. Psikologi Pendidikan. Jakarta: PT. Remaja Grafindo Perkasa. 2005.

Suke Silverius. Evaluasi Hasil Belajar dan Umpan Balik. Jakarta: Grafindo. 1991.

Syaiful Sagala. Konsep Dan Makna Pembelajaran. Bandung: Alfabeta. 2005.

W. gulo. Strategi Belajar-mengajar. Jakarta: Grafindo. 2008.

\section{Akses daring}

Wikipedia. Multimedia: http://en.wikipedia.org/ (diakses 22 Juli 2010)

Wikipedia. Multimedia: http://en.wikipedia.org/ (diakses 20 Desember 2020)

Wikipedia. Multimedia: http://en.wikipedia.org/ (diakses 15 November)

Wina.2011. Strategi Pembelajaran Berorientasi Standar Proses Pendidikan. Bandung: Kharisma Putra Utama.

Www. Artikel bagus.com (diakses 20 april 2013)

Zamroni. 2007. Meningkatkan Mutu Sekolah: Teori, Strategi Dan Prosedur. Jakarta: PSAP.

Zuhdi Tafqihan, 2011, Karakteristik Dan Pemilihan Media Pembelajaran Dalam E-Learning, Cendikia: Jurnal Kependidikan dan kemasyarakatan, Vol. 9 No. 2, 2011 